\title{
Irradiation Protects Against Pancreatic Islet Degeneration and Hyperglycaemia Following Streptozotocin Treatment of Mice
}

\author{
M. Nedergaard ${ }^{1}$, J. Egeberg ${ }^{2}$ and H. Kromann ${ }^{3}$ \\ ${ }^{1}$ Hagedorn Research Laboratory, Gentofte, ${ }^{2}$ Department of Medical Anatomy (B), University of Copenhagen, and \\ ${ }^{3}$ Steno Memorial Hospital, Gentofte, Denmark
}

\begin{abstract}
Summary. Five daily injections of streptozotocin $(40 \mathrm{mg} / \mathrm{kg})$ produce islet inflammation, necrosis of pancreatic B cells and hyperglycaemia in the mouse. Anti-pancreatic autoimmunity has been suggested as part of the cause of these events. We have studied the possible effect of total-body irradiation in long-term studies (246 days) and report here that insulitis, islet necrosis and insulin depletion are reduced after irradiation. In parallel the level of hyperglycaemia is reduced. It is con-
\end{abstract}

cluded that immunological mechanisms are to some extent responsible for the development of streptozotocin-induced diabetes.

Key words: Experimental diabetes, mouse, streptozotocin, irradiation, immunosuppression, morphology, insulitis, autoimmunity.
Infiltration of inflammatory cells in pancreatic islets of diabetic patients was a common finding before the introduction of insulin therapy [1]. This picture was rediscovered in newly diagnosed insulin-dependent diabetes mellitus $[2,3]$ and autoimmune mechanisms were suggested as a possible mechanism in B cell destruction [4].

Such mechanisms have been suggested also in mice treated with low doses of streptozotocin (STZ) [5]. This model of experimental diabetes is characterized by insulitis associated with graduate onset hyperglycaemia and hypoinsulinaemia $[5,6]$. The combined treatment with 3-o-methyl-D-glucose, a non-metabolised glucose analogue, and antilymphocyte serum abolished the STZ-induced insulitis and hyperglycaemia [7]. The combined treatment with 3-o-methyl-D-glucose and total body irradiation was reported also to prevent the development of hyperglycaemia [8].

We report here the effect of total-body irradiation, as the only immunosuppressive treatment, on the development of pathological changes and hyperglycaemia in the low-dose STZ model.

\section{Material and Methods}

Male mice of the Fl hybrid strain C3 D2 Fl/BOM (DBA/2 $\mathrm{J}$ o $\times \mathrm{C} 3 \mathrm{H} / \mathrm{Tif} \%$ ) (Gl. Bomholtgaard, Ry, Denmark) aged 8 to 9 weeks were caged in groups of five with free access to water and standard mouse chow (Rostock mixture, Korn og Foderstofkompagniet, Viby, Denmark). The animals were given five daily IP injections at $10.00 \mathrm{~h}$ of either STZ $(40 \mathrm{mg} / \mathrm{kg}$ body weight; lot. no. 60140 ,
Upjohn, Kalamazoo, Michigan, USA) dissolved (10 g/l) in icecold physiological saline solution immediately before use, or saline solution. Pilot experiments indicated that this regimen of STZ treatment produced a degree of hyperglycaemia similar to that following IP injections of STZ dissolved in acid buffer. Half the animals were totalbody irradiated (450 Rad) without anaesthesia at $08.00 \mathrm{~h}$ on the first day of injection as previously described [9]. Random blood glucose [10] was determined by weekly samples at $10.00 \mathrm{~h}$. For space-saving reasons some non-selected animals were sacrificed 52 days after the first injection. Methyl-violet-stained leucocytes in blood were counted at different time points. On the same day as blood glucose had been estimated, pancreases were removed from ether-anaesthetised animals, fixed in 4\% phosphate-buffered formalin and embedded in paraffin. Sections were stained with haematoxylin-eosin and aldehyde fuchsin [11]. Slides were numbered in arbitrary sequence and read independently by two investigators. The first 10 islets seen on each slide were evaluated. In each animal the following features were scored (0-3): (1) degree of mononuclear cell infiltration in islets of Langerhans; (2) degree of necrosis and hydropic degeneration with the formation of vacuoles in islet cells; (3) degree of fibroblast invasion into islets; (4) degree of aldehyde-fuchsin depletion. For example score 0 was used if $<25 \%$ of the islet cells showed signs of degeneration; score 1 if the percentage was 26-50; score 2 if the percentage was $51-75$, and score 3 if the percentage was above 75 . Individual scores were used to compare experimental groups.

Results are expressed as means \pm SEM for the numbers of observations shown in parentheses throughout. The significance of differences was tested by Wilcoxon's two-sample location test.

\section{Results}

Total-body irradiation produced pronounced leucocytopenia, which reverted to normal 4 weeks later (Table 1). STZ treatment did not affect leucocyte 
Table 1. Blood leucocyte counts in C3 D2 F1 mice in the experimental groups shown

\begin{tabular}{|c|c|c|c|c|}
\hline \multicolumn{5}{|l|}{ Treatment } \\
\hline STZ & 0 & 0 & + & + \\
\hline \multicolumn{5}{|c|}{$\begin{array}{l}\text { Leucocyte counts } \\
\text { (cells } / \mu 1)\end{array}$} \\
\hline $\begin{array}{c}(\text { cells } / \mu 1) \\
\text { Day } 1\end{array}$ & \multicolumn{4}{|c|}{$7850 \pm 13(40)$} \\
\hline Day 10 & $7900 \pm 34(5)$ & $890 \pm 22$ & $7710 \pm 34(5)$ & $875 \pm 29$ \\
\hline Day 28 & $8010 \pm 42(5)$ & $7800 \pm 54$ & $7955 \pm 80(5)$ & $7940 \pm 47$ \\
\hline
\end{tabular}

Results expressed as mean \pm SEM. Numbers of animals in parentheses. Leucocytes were counted the day before and 2,10 and 28 days after the first of five daily injections of saline solution or STZ. Some animals were total-body irradiated (450 Rad) before the initial injection

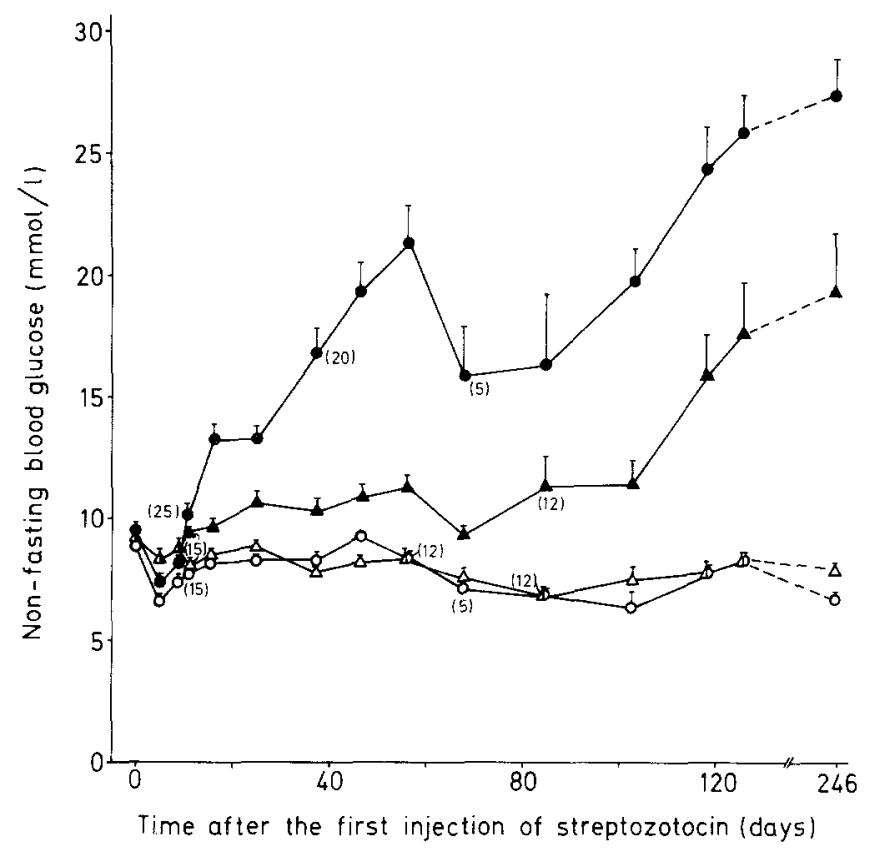

Fig. 1. Random blood glucose in four experimental groups of C3 D2 F1 mice days $0-246$ following the initial treatment. Results expressed as mean \pm SEM for the numbers of animals shown in parentheses, the number being unchanged if not shown. Key: $\mathrm{O}_{-} \mathrm{O}$ : five daily injections of physiological saline solution [25]; $\triangle-\Delta$ : total-body irradiation (450 Rad) and injections of saline solution [30]; - : five daily injections of STZ $(40 \mathrm{mg} / \mathrm{kg})[30] ; \mathbf{\Delta}$ : total-body irradiation (450 Rad) and injections of STZ [45]. Animals treated with STZ had higher blood glucose values after day 12 than animals receiving additional treatment with $\mathrm{X}$-irradiation $(p<0.01)$

counts. Irradiated animals were in good condition and none died during the study period of 246 days. Irradiated and non-irradiated animals had similar body weights throughout the study period. In contrast STZ-treatment impaired body weight increase by approximately $12 \%$ irrespective of irradiation. Irradiation did not affect blood glucose in animals injected with saline (Fig.1). Progressively increasing hyperglycaemia was observed in animals treated with STZ, while animals treated with both STZ and total-body irradiation demonstrated a lower and delayed increase in blood glucose level.
Morphological investigations were performed on days 10, 38, 81 and 246 after the first injection of STZ or saline (Table 2). After 10 days (Fig. 2) a marked mononuclear cell infiltration of the islets, islet necrosis and diminished staining by aldehyde-fuchsin was recognized in STZ-treated animals, whereas animals which had also been irradiated demonstrated significantly fewer changes. After 38 days (Fig. 2), insulitis had almost disappeared. Necrosis and aldehyde-fuchsin depletion remained less pronounced in animals which had also been irradiated. Later on an increasing degree of fibrosis was observed in remaining islets of STZ-treated animals. Detailed information is given in Table 2, which shows that means of morphological scores were higher or equal for all qualities in STZ-treated animals compared with irradiated and STZ-treated animals.

\section{Discussion}

Long-term studies with mice - some of which were total-body irradiated - treated with five daily injections of STZ, revealed that X-irradiation delays and diminishes the development of hyperglycaemia. This protection was also demonstrable by morphological investigations, a feature not described previously.

While a steadily increasing blood glucose level was observed in STZ-treated animals - even after insulitis had almost disappeared - X-irradiation prevented such increase for about 80 days. Whether such prolonged protection is due to suppression of the immune system by mechanisms different from simple leucopenia, which recovered before 28 days, is not known. Interestingly insulitis was not observed in irradiated and STZtreated animals at 81 days, at which time the diabetes protective effect apparently ceased and development of hyperglycaemia began. This may indicate that part of STZ-induced pancreatic B cell damage is independent of insulitis as recognized by light microscopy.

The mechanism of B-cell necrosis in this model of experimental diabetes is not established. The effect is known to depend on the sex of the recipient $[9,12]$, and 

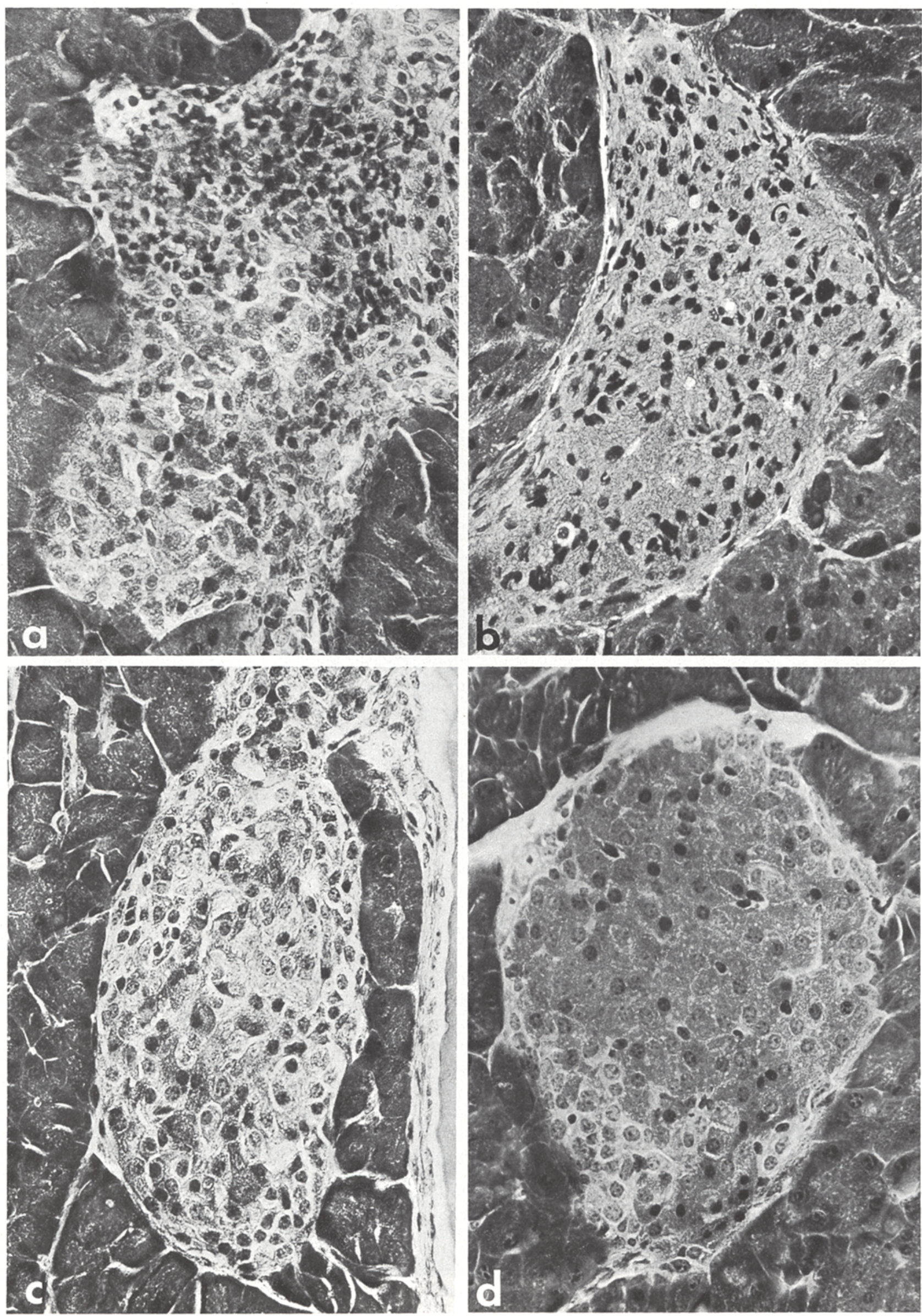
Table 2. Scores for morphological changes in islets of Langerhans following varying treatments of C3 D2 F1 mice

\begin{tabular}{|c|c|c|c|c|c|c|}
\hline \multicolumn{7}{|c|}{ Treatment } \\
\hline STZ & & 0 & 0 & + & & + \\
\hline \multirow{3}{*}{$\begin{array}{c}\text { Day } \\
10\end{array}$} & & \multicolumn{5}{|c|}{ Scores for morphological changes } \\
\hline & Insulitis & $0.2 \pm 0.2(5)$ & $0.2 \pm 0.1(15)$ & $2.9 \pm 0.1(5)$ & a & $1.7 \pm 0.2(15)$ \\
\hline & Necrosis & $0.0 \pm 0.0(5)$ & $0.8 \pm 0.2(15)$ & $2.4 \pm 0.4(5)$ & a & $1.3 \pm 0.2(15)$ \\
\hline \multirow{4}{*}{$\begin{array}{c}\text { Day } \\
38\end{array}$} & Insulitis & $0.0 \pm 0.0(5)$ & $0.0 \pm 0.0$ & $1.1 \pm 0.5(5)$ & & $0.8 \pm 0.5$ \\
\hline & Necrosis & $1.5 \pm 0.6(5)$ & $1.2 \pm 0.2 \quad(5)$ & $2.9 \pm 0.1(5)$ & a & $1.5 \pm 0.6 \quad(5)$ \\
\hline & Fibrosis & $0.2 \pm 0.2(5)$ & $0.2 \pm 1.0$ & $1.2 \pm 0.4(5)$ & & $1.0 \pm 0.4$ \\
\hline & AF depletion & $0.2 \pm 0.2(5)$ & $0.2 \pm 0.2$ & $3.0 \pm 0.0(5)$ & a & $1.0 \pm 0.4$ \\
\hline $\begin{array}{c}\text { Day } \\
81\end{array}$ & Insulitis & $0.0 \pm 0.0(2)$ & $0.0 \pm 0.0$ & $0.0 \pm 0.0(2)$ & & $0.0 \pm 0.0$ \\
\hline \multirow{3}{*}{$\begin{array}{l}\text { Day } \\
246\end{array}$} & Necrosis & $1.0 \pm 0.0(2)$ & $0.8 \pm 0.4$ & $1.5 \pm 0.5(2)$ & & $0.3 \pm 0.3$ \\
\hline & Fibrosis & $0.0 \pm 0.0(2)$ & $0.3 \pm 0.3$ & $3.0 \pm 0.0(2)$ & & $2.0 \pm 0.0$ \\
\hline & AF depletion & $0.0 \pm 0.0(2)$ & $0.3 \pm 0.3$ & $3.0 \pm 0.0(2)$ & & $2.3 \pm 0.3$ \\
\hline
\end{tabular}

Pathological changes of islets of Langerhans were scored from coded slides and expressed as mean \pm SEM for the number of animals in parentheses. Sections of pancreases were scored 0-3 for degree of insulitis, necrosis, fibrosis and aldehyde fuchsin depletion (AF depletion) at days 10 , 38,81 and 246 after the first of five daily injections of saline solution or STZ. Some animals were total-body irradiated ( $450 \mathrm{Rad}$ ) before the initial injection.

a $p<0.05$, statistically significant

on genetic factors $[13,14]$. An influence of mouse major histocompatibility locus has been reported [15], but could not be confirmed in long-term experiments in this laboratory [14]. Antipancreatic cell-mediated autoimmunity was suggested on morphological grounds and because of the pattern of diabetes development [15]. The effect of lymphocyte transfer is a matter of debate $[12,16,19]$, as is the influence of T-lymphocyte-lack [17, $18,20,21]$. Beattie et al. [17] showed that hyperglycaemia is apparent before the lymphocytic invasion in islets is most marked, which was confirmed [14, 22].

Nevertheless immunosuppressive treatment with anti-lymphocyte serum protected against hyperglycaemia [7]. Our observations with total-body irradiated animals also suggest that anti-pancreatic autoimmunological mechanisms are involved in B cell destruction. We conclude that part of STZ-induced experimental diabetes is autoimmunologically induced.

Acknowledgements. We thank T. Grainger for expert technical assistance and T.Christensen for careful preparation of the manuscript.

\section{References}

1. Schmidt MB (1902) Über die Beziehung der Langerhans'schen Inseln des Pankreas zum Diabetes mellitus. Münchener Med Wochenschr 49: 51-54

2. Gepts W (1965) Pathologic anatomy of the pancreas in juvenile diabetes mellitus. Diabetes 14: 619-633

3. Junker K, Egeberg J, Kromann H, Nerup J (1977) An autopsy study of the islets of Langerhans in acute-onset juvenile diabetes mellitus. Acta Path Microbiol Scand Sect A 85: 699-706

4. Nerup J, Lernmark Å (1981) Autoimmunity in insulin dependent diabetes mellitus. Am J Med 70: 135-141

5. Like AA, Rossini AA (1976) Streptozotocin-induced pancreatic insulitis: New model of diabetes mellitus. Science 193: 415-417

6. Like AA, Appel MC, Williams RM, Rossini AA (1978) Streptozotocin-induced pancreatic insulitis in mice. Lab Invest 38: 470-486

7. Rossini AA, Williams RM, Appel MC, Like AA (1978) Complete protection from low-dose streptozotocin-induced diabetes in mice. Nature 276: 183-184

8. Rossini AA, Like AA, Williams RM (1981) Irradiation protects against low-dose streptozotocin diabetes. Clin Res 29: 420 A (Abstract)

9. Kromann H, Christy M, Nedergaard M, Nerup J (1982) The low dose streptozotocin murine model of Type 1 (Insulin-dependent) diabetes mellitus: Studies in vivo and in vitro of the modulating effect of sex hormones. Diabetologia 22: 194-198

Fig. 2a Islet from non-irradiated mouse 10 days after onset of STZ-treatment showing a pronounced mononuclear cell infiltration and slight degranulation of the islet cells. Aldehyde fuchsin stain $(\times 450)$. b Islet from irradiated mouse 10 days after onset of STZ-treatment. Very few mononuclear cells are present whereas the islet cells seem slightly degranulated as in the previous figure. Aldehyde fuchsin stain $(\times 450)$. $\mathbf{c}$ Islet from non-irradiated mouse 81 days after onset of STZ-treatment. The mononuclear cells have disappeared and the islet cells are degranulated. Aldehyde fuchsin stain $(\times 450)$. d Islet from irradiated mouse 81 days after onset of STZ-treatment. The islet is indistinguishable from islets in normal, untreated animals. Aldehyde fuchsin stain $(\times 450)$ 
10. Kromann H, Lernmark $\AA$, Vestergaard BF, Egeberg J, Nerup J (1979) The influence of the major histocompatibility complex $(\mathrm{H}-2)$ on experimental diabetes in mice. Diabetologia 16: 107-114

11. Gomori $G$ (1939) A differential stain for cell types in the pancreatic islets. Am J Pathol 15: 497-499

12. Rossini AA, Williams RM, Appel MC, Like AA (1978) Sex differences in the multiple-dose streptozotocin model of diabetes. Endocrinology 103: 1518-1520

13. Rossini AA, Appel MC, Williams RM, Like AA (1977) Genetic influence of the streptozotocin-induced insulitis and hyperglycaemia. Diabetes 26: 916-920

14. Kromann H, Christy M, Egeberg J, Lernmark A, Nerup J (1982) Absence of $\mathrm{H}-2$ genetic influence on streptozotocin-induced diabetes in mice. Diabetologia 23: 114-118

15. Kiesel U, Kolb H (1982) Low dose streptozotocin-induced autoimmune diabetes is under the genetic control of the major histocompatibility complex in mice. Diabetologia 23: 69-71

16. Buschard K, Rygaard J (1977) Passive transfer of streptozotocin induced diabetes mellitus with spleen cells. Acta Path Microbiol Scand (C) $85: 469-472$

17. Beattie G, Lannom R, Lipsick J, Kaplan NO, Osler AB (1980) Streptozotocin-induced diabetes in athymic and conventional BALB/c mice. Diabetes 29: 146-150

18. Paik S-G, Fleischer N, Shin S-I (1980) Insulin dependent diabetes mellitus induced by subdiabetogenic doses of streptozotocin: Obligatory role of cell-mediated autoimmune processes. Proc Natl Acad Sci USA 77: 6129-6133

19. Kiesel U, Kolb H, Freytag G (1981) Strain dependency of the transfer of experimental immune insulitis in mice. Clin Exp Immunol 43: 430-433

20. Buschard K, Rygaard J (1978) Is the diabetogenic effect of streptozotocin in part thymus-dependent? Acta Path Microbiol Scand (C) $86: 23-27$

21. Rossini AA, Like AA, Appel MC, Mordes JP, Williams RM (1980) Streptozotocin (STZ)-induced insulitis model in athymic mice. Diabetes 29: $51 \mathrm{~A}$ (Abstract)

22. Bonnevie-Nielsen V, Steffes MW, Lernmark $\AA$ (1981) A major loss in islet mass and $\beta$-cell function precedes hyperglycaemia in mice given multiple low doses of streptozotocin. Diabetes 30: 424-429

Received: 7 April 1982

and in revised form: 14 February 1983

Dr. Hans Kromann

Steno Memorial Hospital

Niels Steensens vej

DK-2820 Gentofte

Denmark 